\title{
Current issues in the regulation of deceptive advertising: some consequences for South Africa
}

\author{
Shahida Cassim* \\ Department of Business Administration, University of Natal, Private Bag X10, Dalbridge. 4014 Republic of South Africa \\ Robert Langton \\ Department of Commerce, Adelaide University, Adelaide, South Australia
}

Received July 1996

\begin{abstract}
The dramatic political changes that have recently taken place in South Africa have focussed attention on the adequacy of the existing controls on deceptive advertising. On the one hand, there is a recognition that. due to the limited access to educational opportunities in the past. the majority of South African consumers might be particularly susceptible to deceptive advertising and thus existing controls might need to be tightened. On the other hand, the new interim Constitution has elevated freedom of speech and access to the media to the status of fundamental rights to which other controls are subject. These rights are likely to provide a basis to challenge both the existing controls and any attempt to tighten the control of advertising content. This article outlines the controls on deceptive advertising that currently exist in South Africa. It then examines the current debate surrounding the need for and the efficacy of such controls.

Die dramatiese politieke veranderinge wat onlangs in Suid-Afrika plaasgevind het, het die aandag gevestig op die doeltreffendheid van die huidige beheer ten opsigte van misleidende reklame. Aan die een kant is daar erkenning dat as gevolg van beperkte opvoedkundige geleenthede in die verlede, die meerderheid Suid-Afrikaanse verbruikers veral gevoelig mag wees vir misleidende reklame. Teenswoordige beheer behoort dus strenger toegepas te word. Aan die ander kant het die nuwe waarnemende Grondwet persvryheid en toegang tot die media verhoog tot die status van fundamentele reg, wat aan ander kontrole onderworpe is. Hierdie regte sal heel waarskynlik as basis dien om beide die huidige beheermaatreëls en enige poging om die kontrole van reklame-inhoude te verskerp, te toets. Hierdie artikel skets die beheer oor misleidende reklame wat tans in Suid-Afrika bestaan. Daarna word die teenswoordige debat oor die behoefte aan en doeltreffendheid van derglike beheermaatreëls ondersoek.
\end{abstract}

*Author to whom correspondence should be addressed.

\section{Introduction}

Advertising is a pervasive feature of modern society. In a market economy, the allocation of society's scarce resources is dependent upon the individual choices of consumers pursuing their own welfare. For the allocation to be efficient, in the sense of maximizing the welfare of society as a whole, these choices must be well informed (Duggan, 1982: 22). Advertising is an important means by which consumers acquire information about the choices available in the market place. It follows that to the extent that if advertising claims deceive consumers society's resources will be wasted. For this reason many countries including South Africa have introduced controls on the content of advertising. These controls usually attempt to prohibit not only claims that are false but also those that are misleading.

Critics suggest that such controls are both unnecessary and undesirable (Nelson, 1974; Singdahlsen, 1991; Craswell, 1991). They argue that consumers are individually well equipped to detect and protect themselves from false advertising claims. Furthermore they are able, collectively, to severely punish advertisers who engage in deceptive advertising. Therefore intervention in the market is unnecessary. Further, such controls are positively harmful in that, not only do they impose additional costs on advertisers which are ultimately borne by consumers, they also stifle the production of accurate and useful information upon which the efficient allocation of society's resources depends (Singdahlsen, 1991). This is because the attemp! to regulate advertising claims (both false and misleading) poses such large definitional problems that advertisers are forced to withhold information that would be highly beneficial to many consumers (Craswell, 1991).

These arguments have been formulated in the context of advanced western economies where consumers have relatively high levels of literacy, education and access to legal remedies. Their applicability to economies where consumers are illiterate, poorly educated and unaware of their legal rights is open to question. The South African economy includes both types of consumers. The vast majority of (mostly black) consumers are poorly educated and largely unaware of their rights as consumers. This fact has been thought to justify a more interventionist approach to the issue of deceptive advertising. For example, Hawthorne argues that:

'The necessity of consumer protection is directly related to the educational level of society. It is obvious that semi-literate or illiterate people require it more than the better educated segment of the population. The argument that the problem of poverty illiteracy and poor education is the task of the sociologist and social worker rather than the lawyer is not valid in the South African context where education is neither compulsory nor freely available. This fact makes consumer protection of paramount importance, and at present, what is available is insufficient' (1987: 9).

Similar views were used to justify the introduction of the Harmful Business Practices Act 1988 which gave the government extensive power to intervene in the market place (Dendy, 1989). For example, Poovalingam stated:

'We have a rural community which is largely uneducated and when they see these misleading advertisements they get taken in by them. That does the 
community a grave disservice and this bill is seeking to put that right. It will also make it impossible for purveyors of commodities to make false claims for their commodities' (1988: col. 13903).

According to Pearce (1995) the view that the special characteristics of the South African market demand controls on deceptive advertising is widely shared within the advertising industry. It is also felt that the self-regulatory system that exists in South Africa at present is ineffective. On the other hand, South Africa has recently adopted a new Constitution that for the first time enshrines the right to freedom of expression and access to the media. It could be argued that the new Constitution requires a less interventionist approach than has been adopted in the past.

This article begins by briefly outlining the controls on false and misleading advertising that currently exist in South Africa. The article then examines the current debate surrounding the need for and the efficacy of such controls. Based on the Economics of Information Model the theoretical and practical problems in trying to regulate advertising claims are highlighted. The article then speculates about the role that the new Constitution might have in the future regulation of deceptive advertising in South Africa. Some suggestions for research are incorporated.

\section{Existing controls on deceptive advertising}

The control of advertising is generally undertaken in two main forms. One is a system of self-regulation by the industry itself and the other is regulation through the machinery of the state. South Africa has opted for a system of self-regulation. The centrepiece of the self-regulatory system in South Africa, is the Advertising Standards Authority (ASA). The ASA publishes a Code of Advertising Practice which sets out rules relating to the advertising of a number of specific products. It also contains a general prohibition against misleading advertising in the following words:

'Advertisements should not contain any statement or visual presentation which, directly or by implication, omission, ambiguity, or exaggerated claim, is likely to mislead the consumer about the product advertised, the advertiser, or about any other product of the advertiser'.

The ASA itself has no power to penalize breaches of the code. Its efficacy comes entirely from the fact that the major advertising media have voluntarily agreed to withhold advertising space from advertisers who fail to abide by the Code (Sinclair \& Barenblatt, 1993: 74).

In addition to the Code, there are numerous pieces of legislation that deal peripherally with misleading advertising. The vast majority of these are limited to specific types of goods or services such as The Attorneys Act 53 of 1979; Foodstuffs, Cosmetics and Disinfectants Act of 1972; Gambling Act 51 of 1965 and many others. Only the Trade Practices Act 1976 contains a general prohibition on deceptive advertising. Section 9 of the Act states, in part:

'No person shall (a) publish or display any advertisement which is false or misleading in material respects or cause such advertisement to be published or displayed'.
A conviction under this section renders a person liable to a fine of R2 000 and two years imprisonment. The limitations of the Act are clear. Firstly, for corporate defendants, the threat of imprisonment is meaningless. Secondly, a fine of R2 000 would be trivial compared to the costs and expected returns from major advertising campaigns.

The acknowledged deficiencies in the Trade Practices Act led to the passing of the Harmful Business Practices Act 1988 (Dendy, 1989: 105). Despite its name, this Act does not directly prohibit any business practice. Instead it sets out the powers and functions of the Business Practices Committee appointed by the Minister of Trade and Industry. The Committee's main function is to investigate complaints referred to it by the Minister or any consumer body. The outcome of an investigation may be a recommendation to the Minister that the practice should be prohibited. The Minister may then issue a notice in the Government Gazette declaring the practice unlawful. It then becomes an offence to engage in the practice, the maximum penalty for which is $\mathrm{R} 200000$ and five years imprisonment.

It is clear from the definitions in the Act that the Committee has the power to recommend a prohibition on deceptive advertising (Dendy, 1989). The term 'harmful business practice' is defined to mean any 'business practice' which:

directly of indirectly, has or is likely to have the effect

of

a.harming the relations between businesses and con-

sumers;

b.unreasonably prejudicing any consumer; or

c.deceiving any consumer;

The teim 'business practice' is defined to include 'any advertising or type of advertising'. However the Committee is essentially an advisory body (De Jager \& Smith, 1995). Complaints relating to advertising content will be resolved in consultation with the Advertising Standards Authority. Indeed the Consumer Code of the Business Practices Committee states that complaints about advertising must be directed to the ASA.

The failure of the Committee to prohibit deceptive advertising would presumably disappoint those who saw the Act as preventing unscrupulous advertisers from exploiting unsophisticated consumers. On the other hand, it would be applauded by those who argue that consumers themselves are more efficient regulators of deceptive advertising than either industry appointed representatives or government appointed experts.

Apart from these direct attempts to control for deception, various related bodies have Codes of Conduct that attempt to do the same. The National Association of Broadcasters, the Independent Broadcasting Authority and the Broadcasting Complaints Commission of South Africa all have codes governing their conduct.

\section{Economics of Information Model as a basis for determining the need for control}

Recent literature (Nelson, 1970; Singdahlsen, 1991; Craswell, 1991), has argued that the market itself provides adequate incentives for advertisers to avoid deceptive advertising and thus intervention in the market is unnecessary. This is because consumers already have the power to detect and punish many 
forms of deceptive advertising. Where they do not have the power to detect deception, consumers protect themselves by maintaining an attitude of healthy skepticism. Therefore the harm caused hy deceptive advertising has, according to this view, heen exaggerated.

This view relies on a model first developed by Nelson (1970) and later extended by Darby \& Karni (1973). This model, which is commonly referred to as the Economics of Information Model or EOI model. distinguishes three types of advertising claims, according to the ease with which consumers can judge the veracity of the claim. The implications of the model can be explained by imagining an advertisement for a new hrand of margarine. To simplify matters let us suppose that the advertisement makes only three claims as follows:

\section{Brand $\mathrm{X}$ margarine}

(a) comes in a convenient plastic tub

(b) tastes just like butter

(c) contains $0 \%$ cholesterol.

An analysis of this advertisement based on the EOI model would classify the first claim as a 'search' claim, because the claim about the container can be evaluated prior to purchase. It is argued that consumers are unlikely to be deceived if this claim is false because they will discover the falsity prior to purchasing the brand. Furthermore, they will have learned to distrust the advertiser in future advertisements and thus the advertiser has a strong incentive to take care in avoiding false search claims. These are therefore of little concern.

The second claim that Brand X tastes just like butter' would be classified as an 'experience' claim since its accuracy can only be discovered through use of the product. Firsttime purchasers might be deceived by such claims. However they will discover this in the process of consuming the product and will not make the same mistake twice. Since most, but not all. advertisers depend on repeat purchases to recover their investment in an advertising campaign, they have an incentive to avoid false experience claims in advertising. Consequently these too should be of little concern.

The third claim - that Brand X contains $0 \%$ cholesterol would be classified as a 'credence' claim since an individual consumer cannot check the veracity of the claim even after consumption of the product. To discover whether the claim is true requires chemical testing quite beyond the resources of the average consumer. Thus consumers would have to consult other sources of information such as that typically published in consumer magazines to discover if this claim is false.

One problem with the model is that it fails to account for the prevalence of so-called 'image advertising' (Pengilley \& Ransom. 1987: 870). Many advertisements, especially television commercials, appear to make no verifiable claims about the adverised product at all. For example. a recent thirty second television commercial for British Airways shows enormous red. white and blue flags being unfurled. The only statement in the advertisement is 'British Airways ... We bring the world together'. Such advertisements may be considered intense credence claims as it would be virtually impossible to discover if these claims are false.

Proponents of the EOI model argue that since consumers know that they will be unable to test the accuracy of credence claims they protect themselves by refusing to rely on them in their purchase decisions. For example Nelson states:

"When all producers have an incentive to say "This

brand tastes best" the consumer can place no credence

whatsoever in any of these claims' (1975: 214).

If this assumption were accurate advertisers would learn that such advertising is unproductive and would therefore stop using them. We would thus expect to find few credence claims in advertising but this is clearly not the case.

Defenders of the EOI model seek to counter this point by arguing that all advertisements, even those that contain no verifiable claims, convey useful information to consumers. This information is firstly that the brand exists and secondly that the producer is prepared to expend funds in advertising. (Nelson, 1974). Since the advertiser would normally need to gain repeat sales to justify the costs of the advertising, it can be inferred that the product performs satisfactorily. Thus the mere fact that a producer is prepared to spend money on advertising provides consumers with a useful cue as to the quality of the product. According to Nelson (1974: 723), this information is quite independent of the actual claims in the advertisement.

Thus, it is argued, the problem of deceptive advertising has been grossly overstated. Consumers have at their disposal two potentially powerful tools to prevent themselves being deceived by advertising claims. The first is a healthy skepticism to non-verifiable claims and the second is the ability to withhold purchases if an advertisement contains verifiable claims that turn out to be false. Thus, according to the EOI model, external regulation is unnecessary.

\section{Validity of the model}

Rather surprisingly, the EOI model has been subjected to little empirical testing (Bond, 1982). Only one reported study has attempted to directly test a central tenet of the model: that consumers are more sceptical of credence claims than experience claims and more sceptical of experience claims than search claims. Ford, Smith \& Swasy (1990) found some support for the model in that respondents were generally more sceptical of experience claims than search claims. However, contrary to the predictions of the model, respondents were no more sceptical of credence claims than of experience claims.

Some indirect support for the model may be provided by the numerous surveys of public attitudes to advertising in the United States. Such surveys consistently show widespread skepticism of advertising claims generally (Calfee \& Ringold. 1987). In the most recently reported study of attitudes to television advertising in the United States (Mittal, 1994), more than two thirds of respondents disagreed that the information provided by television advertising 'aided their buying confidence'.

Comparable studies in the South African context are difficult to find. A recent study by Boshoff \& Du Plessis (1992) claimed to measure 'consumer sentiment towards marketing in a South African context'. They reported that respondents had generally favorable attitudes to advertising. However the validity of their study is severely limited by the fact that it measured the attitudes of white consumers only.

A study undertaken by Impact Information (1995) among 1000 white women and 375 black women concluded the 
following: South African whites' attitudes to advertising in general are becoming increasingly negative. South African blacks are however not yet generally negative to advertising.

Surprisingly little empirical work has been reported on the processing of advertising by hlack consumers in South Africa. Deppe (1974) compared the appeals perceived by a sample of black consumers with those that were intended by the advertiser. He found that in half the cases, there was a substantial divergence between the perceived and intended appeals. A second study (Deppe, 1975) investigated adult urban Blacks' attitudes to advertising. The majority of respondents were found to hold generally favourable attitudes to advertising. In response to more specific questions. about half 'felt that advertising generally presents a true picture of the products advertised'. Over $75 \%$ recalled at least one advertisement that they considered to be dishonest.

Cassim \& Douglas (1992) investigated the extent to which the motives of advertisers were recognized by rural black youths aged between eight and 22 . They concluded that a large proportion of respondents seem to be unaware of the advertiser's intention in producing the advertisement and were generally trustful of the claims made about the product. Older respondents, those with more formal education, and those with higher exposure to advertising, showed a greater awareness of the intentions of advertisers and were more sceptical of the content of advertisements (Cassim \& Douglas, 1992: 10).

Further support for the view that less sophisticated consumers tend to be less sceptical of advertising claims is provided by overseas studies in developing countries. Separate studies in Thailand (Thorelli \& Sentell, 1982) and Kenya (Waruingi, 1980) both concluded that rural consumers are more trustful of advertising claims than their urban counterparts.

Thus to the extent that the EOI model relies on consumers being sceptical of advertising claims they cannot verify, it may be less applicable to South Africa than to advanced western economies. This is because the available evidence suggests that the majority of South African consumers appear to be generally trustful of advertising claims.

\section{Costs of skepticism}

The above clearly makes a case for the formulation of a system to monitor advertising in situations where there are levels of trust that provide the potential for deception.

However, even in the case of advanced or developed economies, where skepticism prevails, it does not follow that systems designed to eliminate false advertising claims will be irrelevant or ill-conceived. While a strategy of skepticism provides useful protection against advertising claims that turn out to be false, it is a self-defeating strategy in respect of advertising claims that are true. A reliance on skepticism is thus inefficient in communicating claims that are true. In effect, it amounts to throwing out the baby with the bathwater.

Therefore, proponents of regulation emphasize the role that regulation can play in replacing consumers reliance on skepticism and thereby increasing the amount of useful information that can be obtained from advertising (Saunders, 1991). This position assumes that a workable rule can be formulated that accurately distinguishes between deceptive advertisements and those that provide true and useful information.

However, formulating an adequate conceptualization of deception is fraught with problems of formulating standards that may be applied. There are firstly problems of interpretation. The use of puffery will complicate efforts at recognizing deception. Secondly the issue of beliefs must be addressed. Thirdly, the materiality issue needs to be examined.

\section{Interpretation issue}

Most rules that have been devised to regulate deceptive advertising prohibit not only claims that are false but also those that are misleading. It is this feature, more than any other, that causes difficulty in the application of the rules (Craswell, 1991). To decide if an advertising claim is false is, conceptually speaking, a relatively simple matter. This simplicity is due to the fact that consideration need only be given to the literal meaning of the advertisement. For example, the claim that 'Brand X margarine contains $0 \%$ cholesterol' has only one literal meaning and thus it is reasonably clear what tests are required to test the accuracy of the claim.

However if we broaden our concerns to claims that, although true, are misleading, we are forced to consider not only the literal claim but also claims that might be implied. In the above example, possible implied claims include:

- 'Brand X is the only margarine with $0 \%$ cholesterol'

- 'Brand $\mathrm{X}$ is a suitable food for those concerned about heart disease'

- 'Brand $\mathrm{X}$ is better than butter for those concerned about heart disease'

Even though the literal claim is found to be true, the advertisement will be misleading if consumers interpret it to be implying one of these statements and the statement happens to be false. Thus the first problem that must be faced in determining if an advertisement is misleading is one of interpretation. Which of the large number of conceivable statements should be treated as being implied by an advertisement?

Because advertising, especially television advertising, is typically addressed to a very large audience and this audience varies greatly in its educational and prior experiences, it is likely that different members of the audience will draw different inferences from the advertisement. This is likely to be the case even where we consider only those members of the audience that are potential purchasers of the product or only those that fall within the advertisers definition of the target market. Thus it seems that any rule that seeks to regulate implied claims will need to specify what proportion of the audience must perceive the alleged claim before it is legitimate to conclude that the advertisement is misleading. This is referred to in the literature as the ' $n$ percent issue' (Jacoby \& Small. 1975).

Neither of the extreme positions are attractive. The first would hold that an advertisement is misleading if even one person perceives the advertisement to be implying a claim that is false. This would render virtually all advertisements misleading. The other extreme would hold that an advertisement is not misleading unless $100 \%$ of the selected group perceive the advertisement to be implying a claim that is false. Neither does the figure of $50 \%$ seem appropriate. To adopt this position is to recognize that an advertisement is 
acceptable where up to half the audience may be acting under a false assumption in purchasing the product. The problem is thus to define the 'n percent' that is the criterion percentage of consumers who must draw a false inference before the advertisement may be defined as deceptive. The case literature cited from the United States quote FTC figures ranging from 14\% to 20 to 25\% (Schmidt \& Burns, 1988; Preston, 1990).

Schechter (1989) has proposed a three-tiered approach to the problem. He suggests that advertising claims should be categorized according to two criteria: (a) the credibility of the advertisement; and (b) the verifiability of the claim. An advertisement would rank high in credibility if it appeared on network television or in a magazine of large circulation. Thus the media, the message and advertiser prominence have a bearing on credibility. A claim would rank low in verifiability if it was one that could not be evaluated within the first month of purchase. Under Schechter's proposal, different standards would be applied as follows:

1. An advertisement that is high in credibility but low in verifiability would be categorized as misleading if more than $5 \%$ of consumers are likely to interpret the advertisement in the hypothesized fashion.

2. A low credibility advertisement would only be categorized as misleading if an easily verified false claim was perceived by more than $50 \%$ of the audience.

3. Claims ranking high on both criteria (credibility and verifiability) and claims ranking low on both criteria, would be subject to a $25 \%$ standard.

This proposal may be challenged on at least two grounds. The first is that the standards fail to take into account the seriousness of the injury that would result from a consumer being misled. For example, Jacoby \& Small (1975) have argued that pharmaceutical advertisements should be held to a stricter standard than entertainment advertisements because in the first case, the consequence of a consumer being misled could be death or serious injury, whereas in the second case, the result of being misled is simply boredom and a waste of discretionary income.

A more fundamental criticism is that any standard that focusses attention only on the proportion of consumers who perceive a particular (implied) claim is misguided (Gardener, 1975). Even where $100 \%$ of the audience interpret an advertisement to be making a claim that is false, it does not necessarily follow that any consumers have been misled by the advertisement, since all of the audience might recognize the claim to be false and simply refuse to believe it. Such claims are often discussed under the concept of puffery which would appear to resolve the problems of interpretation but in effect complicate the definition of deception.

\section{lssue of false beliefs}

The notion that consumers can only be misled by advertising claims that they both perceive and believe suggests that the most appropriate definition of deceptive advertising is one that focusses on the beliefs held about the product rather than the interpretations placed on the advertisement. Russo, Metcalfe \& Stephens (1981) have argued that the key question about an advertisement is whether consumers form a false belief about the product as a result of exposure to the advertisement.
A problem with this approach to defining deceptive adver. tising is that some consumers are likely to form erroneous beliefs about a product independently of the content of the advertising. Such beliefs can arise through past experience with the product, reports of other users and items in the nonadvertising media. Thus to assess whether an advertisement is deceptive requires a technique that identifies the extent to which any false beliefs held by consumers can properly be attributed to the challenged advertisement. Various such techniques have been proposed. One involves a comparison between the beliefs held by those who have seen the advertisement with those who have not. If the proportion of those seeing the advertisement who hold the false belief is greater than the proportion who did not see the advertisement, then the advertisement is classified as deceptive (Russo $e t$ al. 1981).

An alternative approach requires that the challenged advertisement is first modified so as to remove the allegedly misleading element. In some cases this may require deleting words or other elements from the advertisement. In other cases it may involve adding additional words or other elements to limit possible implications from the advertisement. The sample audience is then divided into two groups. One group is shown the original advertisement and the other is shown the 'corrected' advertisement. If the level of false beliefs is higher in the first group the advertisement is classified as deceptive (Craswell, 1991).

This definition avoids the problem of having to specify some arbitrary proportion of the audience as critical for determining whether an advertisement is deceptive. Instead it concentrates attention on whether the advertisement has engendered a greater proportion of false beliefs than some other advertisement that could have been produced in its place. However, this approach, along with previous approaches, may be criticized on the basis that some false beliefs are immaterial to consumers' purchasing decisions.

\section{Materiality issue}

So far the discussion has assumed that if an advertisement conveys, either directly or by implication, information that is false and this information causes its audience to form false beliefs about the advertised product, then consumers are going to be prejudiced by the advertisement. This assumption will only be true where the false belief is about a feature of the product that is important to consumers (Armstrong, Gurol \& Russ, 1979: 238). For example, if the only thing that consumers care about in choosing between different brands of margarine is its similarity to butter, then the fact that an advertisement falsely implies that Brand $X$ comes in a biodegradable container will have no effect on purchase patterns. No one will be misled in the sense that they bought the wrong product due to the false claim.

The principle that only false beliefs that are material to purchase decisions should be forbidden by a rule prohibiting deceptive advertising (a principle expressly adopted by section 9 of the Trade Practices Act), raises a similar problem to that discussed above. Namely that different people value product attributes differently. Out of all margarine buyers, an unknown proportion will be attracted to one with a biodegradable container. In addition the issue of materiality could be 
interpreted to refer to the actual harm caused to the consumer as a result of having been deceived by the false claim made in the advertisement. Thus, it appears we cannot avoid the problem of specifying some critical proportion of consumers for whom the false claim must be influential before the advertisement should be categorized as deceptive.

Thus understanding the possible interpretations of advertising claims, determining the inferences that derive from these claims, questioning whether these contribute to false beliefs and examining the importance of these beliefs to the purchase decision are all factors that compound the problem of conceptualizing deception in advertising. Furthermore, determining the extent of the harm caused by the false belief/s really hampers the determination of workable rules and/or regulation.

\section{South African context}

South Africa is currently in the process of adopting a new Constitution which accords a new status to freedom of Speech. Section $15(1)$ is as follows:

'Every person shall have the right to freedom of speech and expression, which shall include freedom of the press and other media and the freedom of artistic creativity and scientific research'.

The fact that this right is extended to corporations as well as natural persons (section $7[3]$ ) suggests that advertising and other forms of commercial speech are within the scope of the Constitutional protection. The rights protected by the Constitution may be limited only to the extent that the limitation is reasonable and justifiable in an open and democratic society based on freedom and equality (section 33). The courts are expressly given power to declare invalid any law or government activity that conflicts with these principles (section 7[1])

In the United States, the constitutional guarantee given to freedom of speech has been used to challenge the validity of laws and government policies designed to minimize deceptive advertising. The current US position seems to be that (truthful) advertising and other forms of commercial speech although not equivalent to other forms of protected speech, enjoy some protection under the Constitution. This position is based on the view that the success of a free market economy requires that consumers are adequately informed about market place choices. However false advertising confers no economic benefits and consequently is not protected by the Constitution. Therefore laws prohibiting deceptive advertising constitute a reasonable and justifiable limitation on the constitutional right to free commercial speech (Schmidt \& Burns, 1988).

This position conveniently ignores the difficulties in providing an adequate definition of misleading advertising. For example, a definition that entailed that an advertisement was misleading even if only $1 \%$ of the audience (mis)interpret it to be implying a claim that is false, would effectively render all advertisements misleading and therefore illegal. Given the disparity in educational backgrounds among South African consumers, a standard as high as $30 \%$ might still have this effect.

Any advertiser in South Africa runs the risk that information that would be useful to highly educated and informed consumers will be misinterpreted by those with less education or access to other sources of information. Similarly advertizing claims that would clearly be recognized as metaphors by the first group might well be interpreted as making literal claims by the second group. These risks are particularly acute for television advertisements given television's diverse audience.

In the absence of any clear standard, it is virtually impossible to know whether a particular advertisement infringes the rules. This uncertainty constitutes a de facto restriction on the right to free truthful commercial speech since it inevitably means that advertisers must err on the side of caution and thus withhold useful information from the market. This will lead to consumer choices being less informed than they might otherwise be which undermines the point of extending constitutional protection to truthful commercial speech (Singdahlsen, 1991).

The extent to which the South African Constitutional Court is prepared to grapple with these issues remains to be seen.

\section{Implications and suggestions for further research}

It is clear from the discussion presented that the regulation of deceptive advertising for South Africa is a complex issue as it is in other parts of the developed world. The problems of definition have highlighted the difficulty in formulating workable rules. Indeed the legal standards used by the Federal Trade Commission in the United States have been challenged.

The particular circumstances (lowly sophisticated consumers and high levels of trust in advertising) that prevail in South Africa make the issue of deceptive advertising a relevant and important one. It appears from the overview of the current systems for the regulation of advertising that South Africa does indeed have the mechanisms in place. The issue now revolves around the manner in which these mechanisms may be exercised to control deceptive advertising. It is clear that empirical research is needed in South Africa to answer the questions raised in the discussion.

Perhaps the first issue that needs to be addressed even before tackling the definitional challenges is an assessment of the levels of skepticism of advertising that exists in South Africa. As expressed in the article, healthy skepticism should provide a powerful tool against deception. We need to assess on a regular basis the levels of skepticism (which for practical purposes has been translated into trust in advertising) particularly in the less sophisticated segment of South Africa's population and the extent to which this acts as a defence mechanism against false claims. A small pilot study was undertaken in the Department of Business Administration at the University of Natal with promising results.

A second issue to be addressed is the manner in which the new Constitution will handle the challenges of Freedom of Speech exercised by advertisers. We in South Africa need to question whether advertising will be fully protected or whether it will have the status of 'commercial speech' as exists in the United States. If this is considered there needs to be a careful consideration of the definition of 'commercial speech' even before a course of action is planned.

The definitional problems will also need to be researched in South Africa. The area for investigation under interpretation relates to using the severity of the consequences of making the wrong inference versus the criterion of consumers making 
the inference for the purposes of setting standards to control for deception in advertising. Moreover one would need to examine the extent to which the claims inform the purchase decision of the consumers in question. The issue of materiality and whether such consumer complaints should be left to common law for redress needs to be evaluated.

This article could therefore serve as the basis for some carefully thought out empirical research that could contribute to the development of knowledge on deception that would serve towards the formulation of policy for South Africa.

\section{Acknowledgement}

The research was conducted while the second-named author was a visitor at the Department of Business Administration, University of Natal, Durban. The authors wish to thank Professor David Coldwell and the Journal reviewers for the helpful comments on earlier versions of this article.

\section{References}

Armstrong. G.M., Gurol, M.N. \& Russ, F.A. 1979. 'Detecting and correcting deceptive advertising', Journal of Consumer Research, 6: $237-246$.

Bond. E. 1982. 'A direct test of the lemons model: the model for used pick-up trucks', American Economic Review, 72: 836-842.

Boshoff, C. \& du Plessis, A.P. 1992. 'South African consumer sentiment towardsmarketing', South African Journal of Business Management. 23: 17.

Calfee, J.E \& Ringold, D.J. 1987. 'Consumer skepticism of advertising: what do the polls show?'. In Houston. M.J. (ed.). Advances in consumer research, 15, Provo, UT: Association for Consumer Research.

Cassim, S.B. \& Douglas, T.A. 1992. Understanding the intentions of advertisers: a study of rural black youth of the Kwa Zulu Natal Region. Unpublished working paper, Department of Business Administration. University of Natal, Durban.

Craswell, R. 1991. 'Regulating deceptive advertising: the role of cost-benefit analysis', Southern California Law Review, 64: 549604.

Darby, M.R. \& Karni, E. 1973. Free competition and the optimal amount of fraud', Journal of Law and Economics, 16: 67-88.

De Jager. S. \& Smith, E. 1995. Advertising and the law. Durban: Butterworths.

Dendy, M. 1989. 'Pitfalls of advertising: harmful business practices', Businessman's Law, 18:105-108.

Deppe, R.K. 1974. A comparative study of motives observed in selected pictorial advertisements directed at the Bantu. Bureau of Market Research Report, No. 39. Pretoria: University of South Africa.

Deppe R.K. 1975. A study of the attitudes of urban Blacks to advertising. Bureau of Market Research, No. 48. Pretoria: University of South Africa.

Duggan, A.J. 1982. The economics of consumer protection: a critique of the Chicago School case against intervention. Adelaide Law Review Research Paper No. 2.

Ford, G.T.. Smith, D.B. \& Swasy, J.L. 1990. 'Consumer skepticism of advertising claims: testing hypotheses from economics of information'. Journal of Consumer Research, 16: 433-441.
Gardner, D.M. 1975. 'Deception in advertising: a conceptual approach', Journal of Marketing, 39: 40-46.

Hawthorne, L. 1987. 'Consumer protection'. The South African Consumer. Third Quarter: 69.

Impact Information. 1995. The viewers views of advertising. Commap in the context of Adcare System Update. Johannesburg: Impact document.

Jacoby, J. \& Small, C. 1975. 'The FDA approach to defining misleading advertising', Journal of Marketing, 39: 65-68.

Mittal. B. 1994. 'Public assessment of TV advertising: faint praise and harsh criticism', Journal of Advertising Research, 34: 35-53.

Nelson, P. 1970. 'Information and consumer behaviour', Journal of Political Economy, 78: 311-329.

Nelson, P. 1974. 'Advertising as information', Journal of Political Economy, 83: 729-7.54.

Nelson, P. 1975. 'The economic consequences of advertising', Journal of Business, 48: 213-229.

Pearce, J. 1995. 'In a huff over puffery?', Weekly Mail and Guardian, 13 April 1995: 4.

Pengilley, W. \& Ransom, A.A. 1987. Federal deceptive practices and misleadinga dvertising law: judgments, materials and policy. Sydney: Legal Books.

Poovalingam, P.T. 1988. Parliamentary speech on the introduction of the Harmful Business Practices Bill 1988, House of Delegates Debates, 13 June, Col. 13903.

Preston, I.L. 1990. 'The definition of deceptiveness in advertising and other commercial speech', Catholic University Law Review, 39: $1035-1081$.

Russo, J.E., Metcalfe, B. \& Stephens, D. 1981. 'Identifying misleading advertising' Journal of Consumer Research, 8: 119-131.

Saunders, R.S. 1991. 'Replacing skepticism: an economic justification for competitors actions for false advertising under Section 43(a) of the Lanham Act', Virginia Law Review, 77: 563-601.

Schechter, R. E. 1989. 'The death of the gullible consumer: towards a more sensibledefinition of deception at the FTC', University of Illinois Law Review, pp.571-586.

Schmidt, R.M. Jr. \& Burns, R.C. 1988. 'Proof or consequences: false advertising and the doctrine of commercial speech', Cincinnati Law Review, 56: 1273-1294.

Sinclair, R. \& Barenblatt, M. 1993. The South African advertising book: make the other half work too. 3rd ed. Halfway House: Southern Book.

Singdahlsen, J.P. 1991. 'The risk of chill: a cost of the standards governing the regulation of false advertising under Section 43(a) of the Lanham Act', Virginia Law Review, 77: 339-395.

Thorelli, H.B. \& Sentell, G.D. 1982. Consumer emancipation and economic development: the case of Thailand. Connecticut, USA: Jai Press.

Waruingi, B.C. 1980. 'The consumer and the marketing system in a developing country: Kenya'. Unpublished DBA dissertation, Indiana University, Indiana. Cited in Van der Reis, A.P. 1993. Aspects of marketing in developing countries. Bureau of Market Research Report 199. Pretoria: University of South Africa. 